\title{
EVALUATION OF TREATMENT SUCCESS IN PATIENTS WHO UNDERWENT TRANSOBTURATOR TAPE SURGERY
}

\author{
Ahmet KARATAS, Bulent DURAN, Tulay OZLU, Onder KOC, Melahat Emine DONMEZ, Arzu GULER \\ Department of Obstetrics and Gynecology, Abant Izzet Baysal University, Medical Faculty, Bolu
}

\begin{abstract}
SUMMARY
Aim: Transobturator tape (TOT), a minimal invasive surgery for patients with urinary incontinence, is also frequently applied in addition to other gynecologic surgeries. Previous studies report a cure rate of 80-92\% with TOT. In this study, we aimed to evaluate treatment success in patients to whom TOT was applied in our clinics. Materials and methods: Patients to whom TOT was applied in our clinics between January 2009 and April 2013 were retrospectively evaluated. Follow up records were investigated to find out our TOT success rate and other urogynecologic problems that developed during follow up. Presence of ongoing urinary incontinence was accepted as TOT failure.

Results: 107 cases to whom TOT was applied and with accessible data were included. Median age of the cases was 59 (26-84). 72\% (n=77) of these were in menopause, 91.6\% (n=98) were multiparous and 59.8\% (n=64) had simultaneous gynecologic surgeries. Most frequent additional operation was vaginal hysterectomy $(n=42,39.3 \%)$. Median postoperative follow up duration was 2.4 years $(0.5$-4years). $13.1 \%(n=14)$ of the cases had ongoing urinary incontinence during follow up. Our TOT success rate was $87.9 \%$. This rate was $87.5 \%$ in cases with and $88.4 \%$ in cases without a simultaneous surgery ( $p>0.05$ ); $85.7 \%$ in postmenopausal and $93.3 \%$ in premenopausal cases ( $p>0.05)$. During follow up, cystocele developed in $8.4 \%$ and cuff prolapsus developed in $11.2 \%$ of the cases. Conclusions: Cure rate of TOT cases in our clinics is in accordance with the numbers in the literature. TOT success rate is not affected from the menopausal status or the application of any other simultaneous gynecologic surgery.
\end{abstract}

Key words: postoperative complications, transobturator tape, urinary incontinence

Journal of Turkish Society of Obstetrics and Gynecology, (J Turk Soc Obstet Gynecol), 2014; Vol: 11, Issue: Pages:

TRANSOBTURATOR TAPE UYGULANAN OLGULARDA TEDAVİ BAŞARISININ DEĞERLENDİRILMESİ

ÖZET

Amaç: Üriner inkontinans tedavisinde minimal invaziv bir cerrahi yöntem olan transobturator tape (TOT), diğer jinekolojik cerrahilere ek olarak da sıklıkla uygulanmaktadır. Geçmiş çalışmalarda TOT ile \%80-92 arasında değişen kür oranları bildirilmiştir. Bu çalışmada, kliniğimizde TOT uygulanan olgularda tedavi başarısının değerlendirilmesi amaçlandı. Gereç ve yöntemler: Ocak 2009-Nisan 2013 tarihleri arasında kliniğimizde TOT uygulanan olgular retrospektif olarak incelendi. Olguların takip kontrollerine ait kayttlar incelenerek TOT başarısı ve takipte gelişen diğer ürojinekolojik problemler değerlendirildi. Devam eden idrar kaçırma şikâyetinin olması TOT başarısızlı̆̆ı olarak değerlendirildi.

Bulgular: TOT uygulanan ve verilerine ulaşılabilen 107 olgu çalışmaya dahil edildi. Olguların ortanca yaşı 59 (2684) idi. \%72'si (n=77) menopozda, \%91.6'ss (n=98) multipar ve \%59.8'ine (n=64) TOT ile eş zamanlı başka operasyonlar uygulanmıştı. En sık yapılan eș zamanlı operasyon vajinal histerektomi idi ( $n=42$, \% 39.3). Olguların

Address for Correspondence: Dr. Ahmet Karataş. Abant İzzet Baysal Üniversitesi Tıp Fakültesi, Kadın Hastalıkları ve Doğum Anabilim Dalı, Bolu. Phone: $+90(505) 6381344$ e-mail: akaratas1973@hotmail.com

Received: 10 October 2013, revised: 30 December 2013, accepted: 06 January 2014, online publication: 08 Janura 2014 
ortalama postoperatif takip süresi 2.4 yll (0.5 - 4 yll) idi. Takip süresinde olguları \% 12.1 'inde $(n=14)$ devam eden idrar kaçırma şikayetinin olduğu gözlendi. TOT başarı oranımız \% 87.9 olarak hesaplandı. Bu oran ek operasyon uygulanan olgularda \% 87.5, ek operasyon uygulanmayanlarda \% 88.4 (p>0.05); menopozda olan olgularda \% 85.7, menopoz öncesi operasyon uygulananlarda ise \%93.3 ( $p>0.05$ ) saptandl. Yine, takipte olguların \% 8.4'ünde sistosel, $\%$ 11.2'sinde kaf prolapsusu geliștiği saptandl.

Sonuç: Kliniğimizdeki TOT vakalarındaki kür oranı literatürdeki rakamlarla uyumludur. TOT başarısı hastanın menopozal durumundan ya da eş zamanlı başka bir jinekolojik cerrahi yapılmasından etkilenmemektedir.

Anahtar kelimeler: postoperatif komplikasyon, transobturator tape, üriner inkontinans

Türk Jinekoloji ve Obstetrik Derneği Dergisi, (J Turk Soc Obstet Gynecol), 2014; Cilt: 11, Sayl: Sayfa:

\section{INTRODUCTION}

Stress urinary incontinence (SUI) is one of the most frequently met problems in the gynecology outpatient clinics effecting $4-35 \%$ of women ${ }^{(1)}$. Successful treatment of this condition which adversely affects the quality of life of a woman besides being a health problem is very important for the patient. Patients may be ashamed of telling this condition to the doctor and may frequently postpone admitting to the doctor. Although conservative methods like vaginal pessaries and pelvic floor exercises may be applied for the treatment of this condition, these methods have a low success rate. In case of failure of these methods, several surgical treatments may be applied. In the recent years, with the growing use of minimally invasive surgeries which have a high success rate and which can be easily applied, patients with a complaint of incontinence are benefitting from this treatment.

Transobturator tape (TOT) surgery, which was first reported in the literature as a minimally invasive surgery, involves the placement of a sling material under the urethra with a transobturator approach ${ }^{(2)}$. The placed sling material mimics the function of the pubourethral ligament which is normally found here and supports the urethra like a hammock. Recently objective and subjective cure rates in the treatment of SUI within 6.5 years of follow up was reported to be $89 \%$ and $83 \%$ by Heinonen et al. ${ }^{(3)}$. Similar numbers were reported in different studies in the literature that evaluated the TOT success rates within different follow up periods $(4,5)$.

In this study, we aimed to evaluate the treatment success in cases that had undergone TOT surgery for the treatment of stress and mixed urinary incontinence.

J Turk Soc Obstet Gynecol 2014;11:

\section{MATERIALS AND METHODS}

In this study cases that were diagnosed to have stress incontinence or mixed incontinence in our clinics with history and physical examination and that had undergone TOT operation between January 2009 and April 2013 were retrospectively evaluated. Cases in which the postoperative follow up information could not be reached were excluded from the study.

Cases were evaluated in terms of clinical and demographic properties including age, gravidity, parity, menopausal status, systemic disease and body mass index (BMI) at the time of surgery and the other surgeries that were applied simultaneously with the TOT surgery. Presence or absence of urinary incontinence in the follow up visits at the first and third month after surgery, and also the presence of a urogynecological problem like cystocele, cuff prolapse in the follow up visits were determined from the patient records. For patients that received anticholinergic treatment after the surgery, only the findings determined prior to the initiation of the drug were investigated in the context of the study. In this way, the success of only the TOT surgery for treatment of urinary incontinence was evaluated in the study. Presence of ongoing urinary incontinence was accepted as "TOT failure".

Data were analyzed by using the SPSS 15 software. Whether TOT success rate differs between cases that are postmenopausal or not, that have or have not undergone vaginal hysterectomy and with a BMI that is $\leq 30 \mathrm{~kg} / \mathrm{m}^{2}$ or $>30 \mathrm{~kg} / \mathrm{m}^{2}$ was evaluated by using chi-square test. Whether there is a difference in the BMI of the patients that had ongoing urinary incontinence during follow up was evaluated by ManWhitney $\mathrm{U}$ test. $\mathrm{P}<0.05$ was considered as statistically significant. 


\section{RESULTS}

107 cases that had undergone TOT operation in our clinics and the follow-up information of whom could be reached were included in the study. Median age of the patients was found to be 59 (26 - 84 years), $72 \%$ of these $(n=77)$ were premenopausal and $91.6 \%(n=98)$ were multiparous (Table I). 59.8\% $(n=64)$ of the cases had undergone another surgery simultaneously with the TOT surgery (Table II). The most frequently performed simultaneous operation was vaginal hysterectomy ( $\mathrm{n}=42,39.3 \%)$.

Table I: Clinical and demographic properties of cases to whom TOT was applied.

\begin{tabular}{lc}
\hline Parameter & $\begin{array}{c}\text { Cases that had } \\
\text { undergone TOT } \\
(\mathbf{n}=\mathbf{1 0 7})\end{array}$ \\
\hline Age, median (minimum-maximum) & $59(26-84)$ \\
Body mass index, mean \pm Standard deviation & $28,5 \pm 3,7$ \\
Gravida, median (minimum-maximum) & $3,7(1-7)$ \\
Parity, median (minimum-maximum) & $2,8(1-6)$ \\
Rote of delivery, number (\%) & \\
Normal & $96(89,7)$ \\
Cesarean & $9(8,4)$ \\
Normal + Cesarean & $2(1,9)$ \\
Menopausal cases, number (\%) & $77(72)$ \\
Presence of systemic disease, number $(\%)$ & $12(11,2)$ \\
$\quad$ Hypertension & $5(4,7)$ \\
Diabetes & $4(3,7)$ \\
Asthma & $3(2,8)$ \\
\hline
\end{tabular}

Table II: Operations that were applied at the same time with TOT and urogynecological problems that were seen in long term follow up.

\begin{tabular}{cc}
\hline Simultaneous surgery, number $(\%)$ & $\mathbf{6 4}(\mathbf{5 9 , 8 )}$ \\
Vaginal hysterectomy & $42(39,3)$ \\
Laparoscopic hysterectomy & $7(6,5)$ \\
Total abdominal hysterectomy & $5(4,7)$ \\
Anterior colporrhaphy & $5(4,7)$ \\
Posterior colporrhaphy & $1(0,9)$ \\
Hysteroscopy & $3(2,8)$ \\
Myomectomy & $1(0,9)$ \\
Long term complication, number $(\mathbf{\%})$ & $\mathbf{3 4}(\mathbf{3 1 . 8})$ \\
Ongoing urinary incontinence & $13(12.1)$ \\
Cystocele & $9(8.4)$ \\
Vaginal cuff prolapse & $12(11.2)$ \\
\hline
\end{tabular}

When the findings in the follow-up visits of the cases were investigated, within a median follow up time of 2.4 years $(0.5-4$ years $), 12.1 \%(n=13)$ of the cases were found to have ongoing urinary incontinence. Our TOT success rate in the treatment of stress incontinence was found to be $87.9 \%$. This rate was $87.5 \%$ in cases that had a simultaneous surgery, $88.4 \%$ in those that did not have a simultaneous surgery $(\mathrm{p}>0.05), 85.7 \%$ in postmenopausal women and $93.3 \%$ in premenopausal women ( $p>0.05$ ). It was found that $8.4 \%$ of the cases had developed cystocele and $11.2 \%$ of the cases had developed cuff prolapse during follow up. BMI values at the time of the operation of the cases that had and that did not have ongoing urinary incontinence were found to be similar $\left(29.27 \pm 2.98 \mathrm{~kg} / \mathrm{m}^{2}\right.$ ve $28.44 \pm$ $3.8 \mathrm{~kg} / \mathrm{m}^{2}$, respectively; $\mathrm{p}=0.348$ ) (Table III). In addition, there was no difference in terms of urinary incontinence in cases with a BMI $\leq 30$ and $>30$ $(p=0.758)$ (Table III).

Table III: Comparison of the clinical and demographic properties of the cases in whom transobturator surgery was successful and was unsuccessful.

\begin{tabular}{|c|c|c|c|}
\hline & $\begin{array}{c}\text { Transobtu } \\
\text { Successful } \\
(\mathbf{n}=94) \\
(87.9 \%)\end{array}$ & $\begin{array}{l}\text { Irator tape } \\
\text { Unsuccessfu } \\
\begin{array}{c}(\mathrm{n}=13) \\
(12.1 \%)\end{array}\end{array}$ & $\mathbf{p}$ \\
\hline Age, median (minimum-maximum) & $56(26-84)$ & $68(40-84)$ & 0.156 \\
\hline Gravida, median (minimum-maximum) & $3.5(1-7)$ & $4(2-5)$ & 0.833 \\
\hline Parit, median (minimum-maximum) & $3(1-6)$ & $3(1-4)$ & 0.885 \\
\hline $\begin{array}{l}\text { Body mass index, } \\
\text { mean } \pm \text { Sandard deviation }\end{array}$ & \multicolumn{2}{|c|}{$28.4 \pm 3.729 .3 \pm 2.98$} & 0.348 \\
\hline Multiparous cases, number (\%) & $86(91.5)$ & $12(92.3)$ & 1 \\
\hline Postmenopausal cases, number (\%) & $66(70.2)$ & $11(84.6)$ & 0.345 \\
\hline $\begin{array}{l}\text { Presence of systemic disease, } \\
\text { number (\%) (HT/DM/Asthma) }\end{array}$ & $9(9.6)$ & 11(84.6) & 0.161 \\
\hline $\begin{array}{l}\text { Simultaneous gynecologic surgery, } \\
\text { number }(\%)\end{array}$ & $56(59.6)$ & $8(61.5)$ & 0.892 \\
\hline Vaginal hysterectomy & $37(39.4)$ & $5(38.5)$ & \\
\hline Laparoscopic hysterectomy & $7(7.4)$ & - & \\
\hline Total abdominal hysterectomy & $4(4.3)$ & $1(7.7)$ & \\
\hline Other & $8(8.6)$ & $2(15.4)$ & \\
\hline \multicolumn{4}{|c|}{ Postoperative urogynecologic problems } \\
\hline Cystocele, number (\%) & $9(9.6)$ & - & \\
\hline Cuff prolapse, number (\%) & $12(12.8)$ & - & \\
\hline
\end{tabular}

\section{DISCUSSION}

Midurethral sling surgeries (MUS's) in the treatment of stress urinary incontinence are accepted as almost the gold standard treatment option ${ }^{(6)}$. Although they were first introduced for the treatment of urethral hypermobility and non-complicated stress urinary incontinence, MUS's are now being applied in more complex cases of urinary incontinence like cases with mixed incontinence and cases that additionally have pelvic organ prolapse ${ }^{(6)}$. A recent study reported $75 \%$ 
and $90 \%$ subjective and objective cure rates after one year of follow up in cases with mixed incontinence that had undergone TOT operation ${ }^{(7)}$. In our study, when SUI and mixed incontinence cases were evaluated together, cure rate was found to be $87.9 \%$. This rate is accordance with the numbers in the literature about the TOT success rates.

After the TOT operation, several complications including vascular (eg. bleeding, hematoma), urologic (eg. bladder perforation, urinary retention), neurologic complications can be seen within short term after the operation. In our patients, none of the short term complications were seen.

As far as we know, there is only one study in the literature that investigates whether the efficacy of TOT operation for the treatment of urinary incontinence differs between the premenopausal and postmenopausal women. In this study which was reported in 2011 by Dursun et al. 45 premenopausal and 49 postmenopausal women to whom TOT was performed for the treatment of urinary incontinence were compared and it was concluded that TOT was more effective in premenopausal women ${ }^{(8)}$. In our study, although the TOT success rate in the premenopausal cases that had undergone TOT operation was higher than that of the postmenopausal cases, the difference was not statistically significant. Whether TOT success rate differs according to the menopausal status needs to be evaluated in studies with a higher number of cases.

Esin et al. evaluated whether BMI had an effect on TOT success rate ${ }^{(9)}$ and they concluded that BMI does not affect TOT success rate. Similarly, in our study, we did not find any difference in the BMI values of the cases that did and did not have urinary incontinence during follow-up. In addition, TOT success rate was found to be similar in cases with a BMI $\leq 30$ and those with a BMI $>30$.

TOT, which is applied easily, can be performed simultaneously with other surgeries in cases that have other pelvic pathologies in addition to incontinence. One of the pelvic pathologies that frequently accompany urinary incontinence is pelvic organ prolapse ${ }^{(10)}$. It was demonstrated that the structure of the connective tissue in cases with pelvic organ prolapse may be different from that of normal women ${ }^{(11)}$, and, this factor may contribute to the development of urinary incontinence in these cases. Vaginal hysterectomy performed for the treatment of pelvic organ prolapse in peri/postmenopausal women will not be adequate for treatment if the patient also has urinary incontinence. TOT, which is performed by a vaginal approach, does not necessitate an abdominal incision or routine cystoscopy due to its minimal risk of bladder injury can be frequently applied in these patients simultaneously with vaginal hysterectomy. Previous studies have demonstrated the efficacy and safety of MUS's in the treatment of SUI(12,13). In this study, the most frequently applied operation in addition to TOT was vaginal hysterectomy. Our TOT success rate in cases that did or did not have additional surgery was found to be similar to the literature.

In the literature, high success and low complication rates are reported for TOT surgery which is one of the minimally invasive MUS surgeries used in the treatment of urinary incontinence that is a frequent problem among women significantly disturbing the quality of life. In our study, cure rates in cases with stress/mixed urinary incontinence that had undergone TOT operation was found to be similar with the numbers in the literature.

The most important limitations of our study are its retrospective nature and the low number of cases. Another limitation of our study was that we investigated SUI and MUI cases as a single group since we took into account the possible defects in the patient records, so, we were not able to give the results of these groups separately. Performance of further prospective studies with a larger number of cases and with a higher statistical power is needed.

\section{REFERENCES}

1. Luber KM. The definition, prevalence, and risk factors for stress urinary incontinence. Rev Urol 2004;6 Suppl 3:S39.

2. Delorme E. Transobturator urethral suspension: mini-invasive procedure in the treatment of stress urinary incontinence in women. Prog Urol 2001;11(6):1306-13.

3. Heinonen P, Ala-Nissilä S, Räty R, Laurikainen E, Kiilholma P. Objective cure rates and patient satisfaction after the transobturator tape procedure during 6.5-year follow-up. J Minim Invasive Gynecol 2013;20(1):73-8.

4. Liapis A, Bakas P, Creatsas G. Efficacy of inside-out transobturator vaginal tape (TVTO) at 4 years follow up. Eur J Obstet Gynecol Reprod Biol 2010;148(2):199-201. 
5. Waltregny D, Gaspar Y, Reul O, Hamida W, Bonnet P, de Leval J. TVT-O for the treatment of female stress urinary incontinence: results of a prospective study after a 3 -year minimum follow-up. Eur Urol 2008;53(2):401-8.

6. Fong ED, Nitti VW. Review article: Mid-urethral synthetic slings for female stress urinary incontinence. BJU Int 2010; 106(5):596-608.

7. Abdel-fattah M, Mostafa A, Young D, Ramsay I. Evaluation of transobturator tension-free vaginal tapes in the management of women with mixed urinary incontinence: one-year outcomes. Am J Obstet Gynecol 2011;205(2):150.e1-6.

8. Dursun P, Bildaci TB, Zeyneloglu HB, Kuscu E, Ayhan A. Transobturator tape operation is more effective in premenopausal women than in postmenopausal women with stress incontinence. Korean J Urol 2011;52(9):612-5.

9. Esin S, Salman MC, Ozyuncu O, Durukan T. Surgical outcome of transobturator tape procedure in obese and non-obese women. J Obstet Gynaecol 2011;31(7):645-9.

10. Holroyd-Leduc JM, Tannenbaum C, Thorpe KE, Straus SE. What type of urinary incontinence does this woman have? JAMA 2008;299(12):1446-56.

11. Yücel N, Usta A, Guzin K, Kanter M, Bilgic E, Ozel NO, et al. Immunohistochemical analysis of connective tissue in patients with pelvic organ prolapse. J Mol Histol 2013;44(1):97-102.

12. Lo TS. Combined pelvic reconstructive surgery and transobturator tape (monarc) in women with advanced prolapse and urodynamic stress incontinence: a case control series. J Minim Invasive Gynecol 2009;16(2):163-8.

13. Yip SK, Pang MW. Tension-free vaginal tape sling procedure for the treatment of stress urinary incontinence in Hong Kong women with and without pelvic organ prolapse: 1-year outcome study. Hong Kong Med J 2006;12(1):15-20. 